\title{
Problemy uszkodzeń zmęczeniowych osi pojazdów szynowych
}

\section{Problems of fatigue damage of axis rail vehicles}

\section{Streszczenie}

Pomimo projektowania osi pojazdów szynowych w zakresie tzw. nieograniczonej wytrzymałości zmęczeniowej, wobec podwyższania prędkości pojazdów oraz występowania złożonych zjawisk eksploatacyjnych i materiałowych, rejestrowane są kolejne przypadki występowania uszkodzeń takich osi. W artykule przedstawiono wyniki badań nieniszczących 120 szt. osi pojazdów szynowych, dla których po ok. 4 latach eksploatacji, dla 8 szt. osi stwierdzono występowanie pęknięć zmęczeniowych. Badania defektoskopowe wykonane metodami ultradźwiękową i magnetyczno-proszkową pozwoliły wytypować element, z którego pobrano próbki do wykonania badań składu chemicznego materiału, pomiarów twardości, badań mikroskopowych i fraktograficznych. Analiza uzyskanych wyników badań wykazała, że przyczyną wykrytych pęknięć zmęczeniowych osi było powstanie pęknięć hartowniczych w obszarze karbu geometrycznego.

\section{Wstęp}

Najstarszym, pochodzącym z połowy XIX stulecia wykresem zmęczeniowym, jest wykres Wöhlera [1], którego konstrukcja została oparta na obserwacjach dotyczących pękania osi wagonowych. Pomimo projektowania takich osi w zakresie tzw. nieograniczonej wytrzymałości zmęczeniowej, wobec podwyższania prędkości pojazdów szynowych oraz występowania coraz liczniejszych złożonych zjawisk eksploatacyjnych i materiałowych, rejestrowane są kolejne przypadki występowania uszkodzeń takich osi, kończące się niekiedy tragicznie, jak w czerwcu 2009 r. w Viareggio, gdzie w wyniku pęknięcia zmęczeniowego osi w wagonie cysterny przewożącej gaz skroplony zginęły 32 osoby, a rannych zostało 27 osób. W przypadku takich katastrof taboru szynowego

Dr inż. Bogusław Ładecki, dr inż. Tadeusz Skowronek - AGH Akademia Górniczo-Hutnicza w Krakowie. często trudne jest ustalenie ich przyczyn, pomimo wcześniejszego prowadzenia odpowiednio dokumentowanych badań eksploatacyjnych, w tym badań nieniszczących.

\section{Badania nieniszczące osi}

W związku ze stwierdzonymi po okresie eksploatacji wynoszącym ok. 4 lata, 3 przypadkami pęknięcia zmęczeniowego na wskroś, w obszarze karbu osi $\varnothing 100$ pojazdów szynowych (rys. 1) przeprowadzono odpowiednie badania i analizy [2], celem znalezienia przyczyn występowania takich uszkodzeń. Badania nieniszczące z wykorzystaniem metody ultradźwiękowej głowic fal podłużnych z powierzchni czołowej dla ok. 120 szt. zamontowanych osi, w 8 przypadkach ujawniły występowanie pęknięć w obszarze karbu geometrycznego. Po demontażu osi z wykrytymi pęknięciami, wykonano 
badania defektoskopowe metoda magnetyczno-proszkową, które potwierdziły wyniki badań metodą ultradźwiękową i pozwoliły uściślić długości pęknięć, które wynosiły: 38, 115, 90, 150, 150 i 18; pełny obwód - 200 oraz 67 mm. Przykładowe pęknięcia wykryte metodą magnetyczno-proszkową pokazano na rysunku 2. Analiza porównawcza długości pęknięć na obwodzie określonych obiema ww. metodami wykazała znaczące różnice w rozmiarach pęknięć. Długość pęknięć określona metodą ultradźwiękową była zwykle mniejsza o kilka do kilkunastu procent, niż określona metodą magnetyczną. Do dalszych badań z osi, dla której metodą magnetyczną wykryto pęknięcie na całym jej obwodzie, wycięto próbkę pokazaną na rysunku 3.

Analiza kierunku rozwoju pęknięcia osi z rysunku 3 wskazuje na występowanie dwóch faz rozwoju pęknięcia. W początkowej fazie pęknięcie rozwija się do

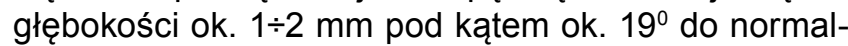
nej do powierzchni walcowej, przy czym na tym etapie można niekiedy zaobserwować występowanie równoległych pęknięć wielokrotnych (rys. 3a). W drugim

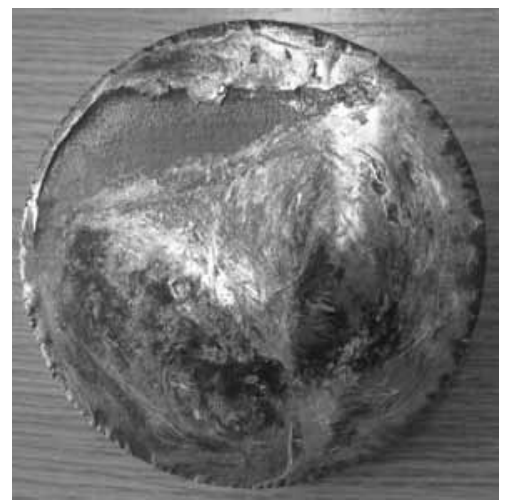

Rys. 1. Przełom zmęczeniowy osi pojazdu szynowego Fig. 1. Fatigue fracture of the rail vehicle axl
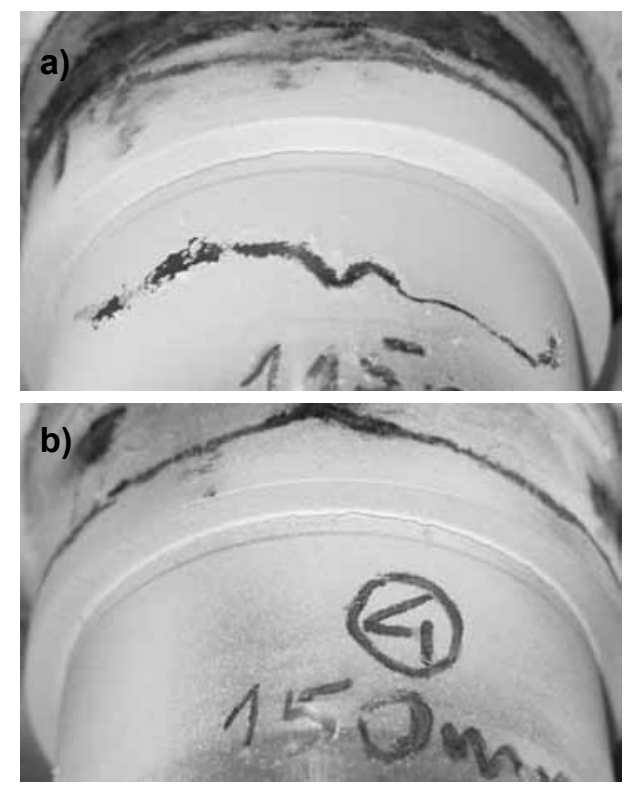

Rys. 2. Pęknięcia osi pojazdu szynowego wykryte metodą magnetyczno-proszkową: a) o dł. $115 \mathrm{~mm}$, b) o dł. $150 \mathrm{~mm}$

Fig. 2. Cracks of the rail vehicle axle detected by magnetic-particle testing: a) with a length of $115 \mathrm{~mm}, \mathrm{~b}$ ) with a length of $150 \mathrm{~m}$
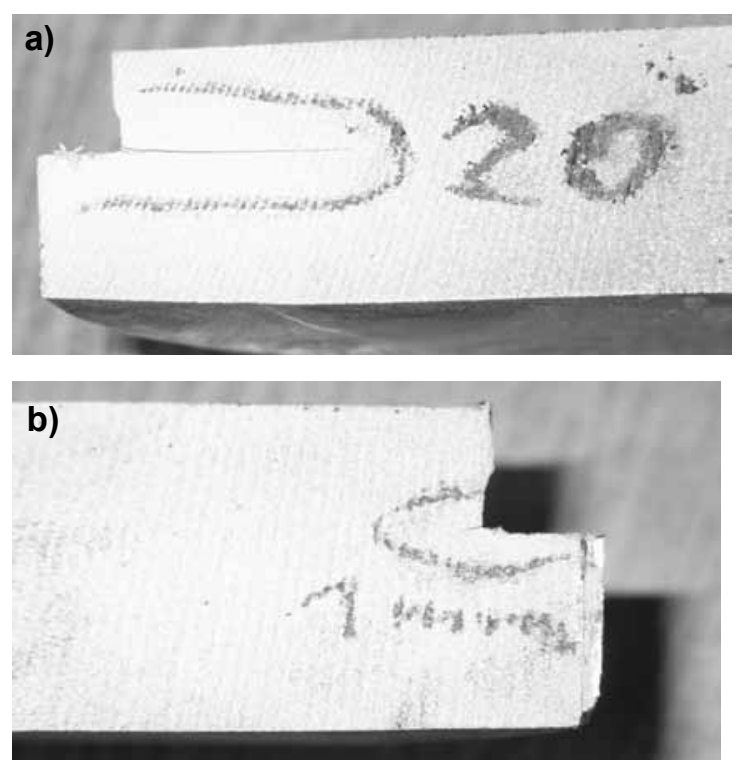

Rys. 3. Próbka wycięta z osi z pęknięciem na całym jej obwodzie: a) widoczna maksymalna głębokość pęknięcia wynosząca $20 \mathrm{~mm}$ b) pęknięcie $1 \mathrm{~mm}$ nie wykryte metodą ultradźwiękową

Fig. 3. A sample cut from the axis with the crack around the entire circumference: a) visible maximum depth of cracks of $20 \mathrm{~mm}$, b) $1 \mathrm{~mm}$ crack not detected by ultrasound

etapie następuje zmiana kierunku pęknięcia, które propaguje dalej w kierunku prostopadłym do osi elementu. Pęknięcie na rysunku 3b nie zostało wykryte metodą ultradźwiękową przy badaniu falami podłużnymi od czoła osi, co uzasadnić można wynikami badań zamieszczonych w pracach [3, 4], które wskazują na bardzo niskie prawdopodobieństwo wykrycia wady o głębokości mniejszej niż $2 \mathrm{~mm}$ metodą ultradźwiękową z wykorzystaniem fal podłużnych wprowadzanych od czoła. Taka metoda badania nie daje również gwarancji wykrycia pęknięć o większych wymiarach, w przypadku występowania naprężeń ściskających, jak również występowania smaru w obszarze pęknięcia, w związku z efektem znacznego osłabienia amplitudy echa wady $[4,5]$.

Przy szybkim tempie rozwoju pęknięć zmęczeniowych rozważanych osi prowadzenie badań eksploatacyjnych metodą ultradźwiękową z wykorzystaniem fal podłużnych wprowadzanych od czoła mogło być przyczyną pęknięć osi na wskroś, a wskutek tego wykolejenia pojazdów szynowych, pomimo prawidłowego nastawienia czułości oraz odpowiedniej staranności prowadzenia badań.

\section{Badania metalograficzne}

Badania metalograficzne wykonano dla obu połówek próbek pobranych z osi, dla której pęknięcie stwierdzono na całym obwodzie (rys. 3). Wykonana analiza składu chemicznego materiału wykazała, że oś wykonano ze stali 36CrNiMo4 (36HNM), przy czym stwierdzono mniejszą o 0,02\% zawartość węgla od wymaganej zgodnie z PN-EN 10083. 

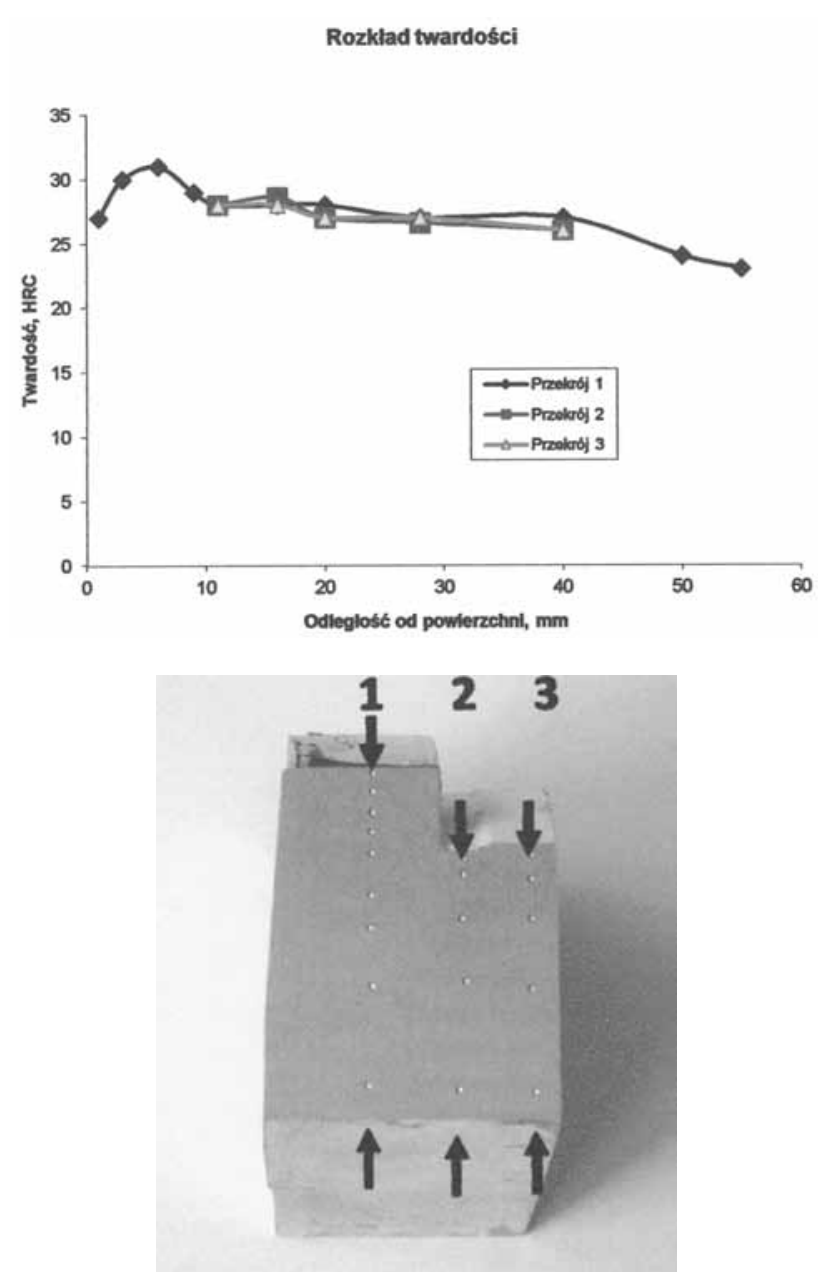

Rys. 4. Wyniki pomiarów twardości w obszarze karbu

Fig. 4. Results of measurement of hardness in the area of the notch

Pomiary twardości metodą Rockwella, wykonane w trzech przekrojach $(1,2$ i 3$)$ w obszarze karbu zestawione na rysunku 4 wykazały, że bezpośrednio przy powierzchni twardość jest nieco niższa niż w odległości $3 \div 5 \mathrm{~mm}$ i ulega dalszemu obniżeniu idąc $w$ kierunki środka przekroju.

\section{Badania mikroskopowe}

Dla drugiej odciętej części próbki z rysunku 3b wykonano próbkę do badań metalograficznych (rys. $5 a$ ), których wyniki dla obszaru 1 pokazano na rysunku $5 \mathrm{~b}$. $\mathrm{Na}$ rysunku $5 \mathrm{~b}$ widoczne są trzy mikropęknięcia, a stal a)

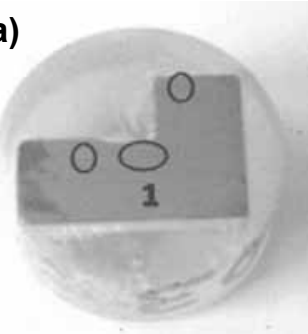

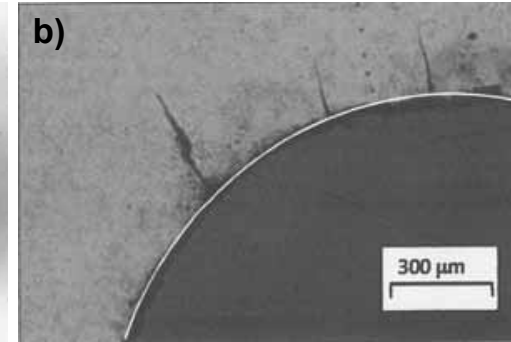

Rys. 5. Badania metalograficzne: a) próbka do przeprowadzenia badań, b) wyniki badań dla obszaru 1 - widoczna mikrostruktura sorbityczna

Fig. 5. Metallographic examination: a) sample for testing, b) test results for the area 1 - visible sorbitic microstructure ma mikrostrukturę sorbitu charakterystyczną dla stali po ulepszaniu cieplnym i wysokim odpuszczaniu. $\mathrm{Na}$ rysunku tym wrysowano okrąg o promieniu $0,9 \mathrm{~mm}$, przy czym projektowa wartość promienia karbu wynosi $1,0 \mathrm{~mm}$.

\section{Badania fraktograficzne}

Badania fraktograficzne skaningowym mikroskopem elektronowym (SEM) wykonano dla próbki pobranej w obszarze występowania głębokiego pęknięcia pokazanym na rysunku 6 . Na tej próbce zaznaczono obszary, dla których wykonano badania SEM: A - miejsce inicjacji pęknięcia, B - przełom zmęczeniowy oraz $\mathrm{C}$ - przełom ciągliwy w miejscu dołamania próbki. Wyniki badań fraktograficznych dla obszarów A, B i C zilustrowano na rysunkach 7-9.

Badania fraktograficzne wykazały, że w obszarze karbu geometrycznego A (rys. 6) zainicjowane zostało kruche międzykrystaliczne mikropęknięcie, od którego rozwinęło się pęknięcie o charakterze zmęczeniowym - obszar B (rys. 8). Badania makroskopowe osi wykonane w obszarze karbu ujawniły występowanie pęknięć o zróżnicowanej głębokości na obwodzie elementu - rysunki 1,3 i 6 , co sugeruje, że są to mikropęknięcia hartownicze.

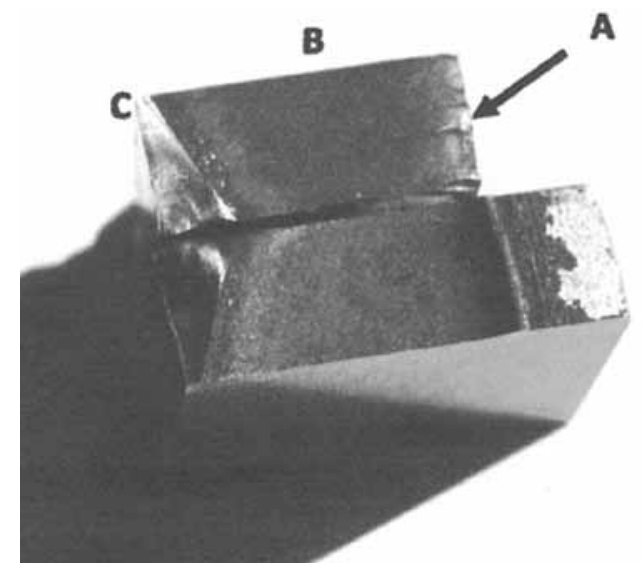

Rys. 6. Próbka do badań fraktograficznych

Fig. 6. Sample for fractographical testing

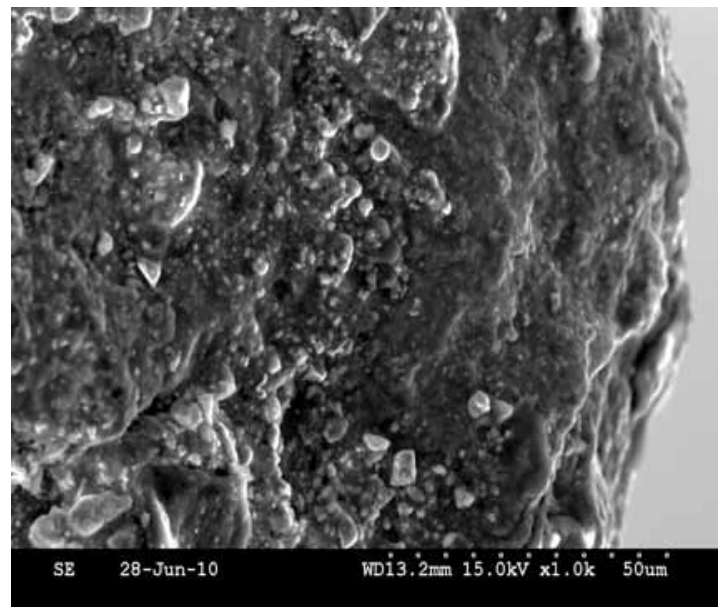

Rys. 7. Przełom kruchy w obszarze A - karbu

Fig. 7. Brittle fracture in the $A$ area notch 


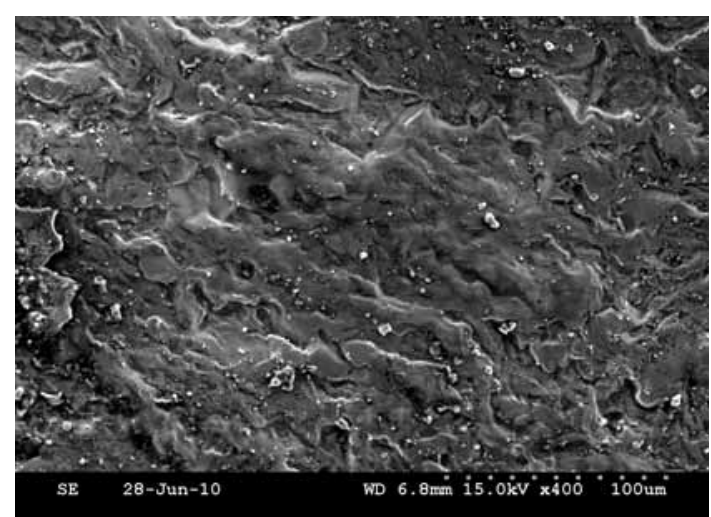

Rys. 8. Przełom zmęczeniowy w obszarze B"z widocznymi liniami zatrzymania pęknięcia

Fig. 8. Fatigue fracture in the $B$ area with visible lines of the cracks stop

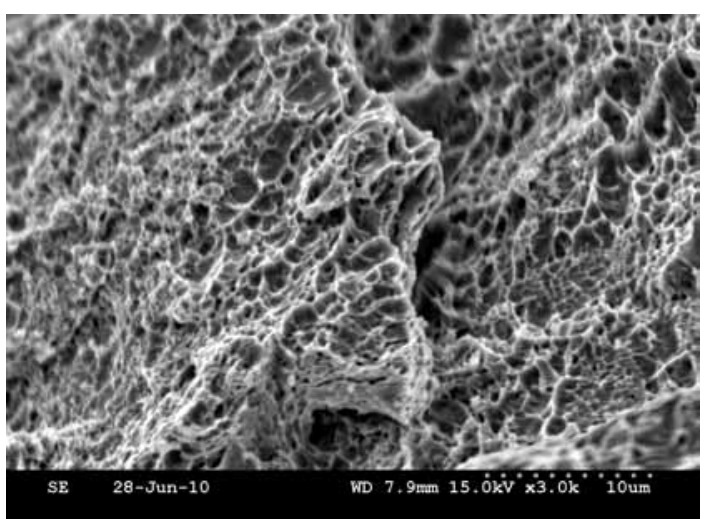

Rys. 9. Przełom ciągliwy w obszarze dołamania C

Fig. 9. Ductile fracture in the area of fracture $C$

\section{Podsumowanie}

Badania defektoskopowe wytypowanej do analizy osi metodą ultradźwiękową i magnetycznoproszkową ujawniły mechanizm rozwoju pęknięcia zmęczeniowego w obszarze karbu rozważanego elementu. W początkowej fazie pęknięcie rozwija

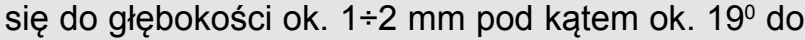
normalnej do powierzchni walcowej, przyjmując niekiedy charakter równoległych pęknięć wielokrotnych. W drugim etapie następuje zmiana kierunku pęknięcia, które w sposób zmęczeniowy rozwija się dalej w kierunku prostopadłym do osi elementu.

Podczas prowadzenia badań metodą ultradźwiękową falami podłużnymi od czoła osi stwierdzono problemy z wykrywaniem pęknięć w początkowej fazie ich rozwoju, co można wyjaśnić na podstawie wyników badań zamieszczonych w pracach $[3,4]$, które wskazują na bardzo małe prawdopodobieństwo wykrycia wad o głębokości $2 \mathrm{~mm}$, a nawet większej, zastosowaną metodą.

Pomiary promienia przejścia w obszarze karbu wykazały, że uzyskana wartość promienia jest mniejsza niż wymagana zgodnie $z$ dokumentacją techniczną $(1 \mathrm{~mm})$ i wynosi ok. 0,9 mm.

Pomiary twardości metodą Rockwella wykazały występowanie lokalnego ekstremum twardości na

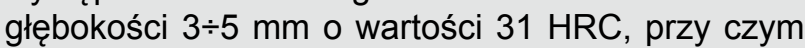

w kierunku środka osi twardość maleje monotonicznie do 23 HRC.

Badania metalograficzne wykazały, że zastosowana stal $36 \mathrm{CrNiMo} 4$ została poddana ulepszaniu cieplnemu, tj. hartowaniu i wysokiemu odpuszczaniu i ma mikrostrukturę sorbityczną.

Badania fraktograficzne dostarczyły informacji o obszarze inicjacji pęknięcia oraz jego późniejszej propagacji. Można przypuszczać, że w miejscu karbu (promień ok. 1,0 mm) powstało kruche międzykrystaliczne mikropęknięcie lub wielokrotne mikropęknięcia, których dalszy rozwój następowałby mechanizmem zmęczeniowym.

Charakter kruchych wielokrotnych pęknięć i ich zróżnicowana głębokość na obwodzie w obszarze karbu geometrycznego (rys. 1, 3, 5b i 6) wskazuje, że są to pęknięcia hartownicze, od których nastąpił dalszy rozwój pęknięć zmęczeniowych w głąb materiału. Niezbyt duża wartość promienia przejścia w obszarze karbu geometrycznego, przyjęta w dokumentacji technicznej na podstawie wykonanej analizy wytrzymałościowej osi, w połączeniu z pojawieniem się „ostrych" kruchych pęknięć hartowniczych, wpłynęła prawdopodobnie na przyspieszenie tempa rozwoju pęknięć zmęczeniowych osi.

\section{Literatura}

[1] Kocańda S., J. Szala J.: Podstawy obliczeń zmęczeniowych. Wydawnictwo Naukowe PWN. Warszawa 1997.

[2] Ładecki B., Skowronek T.: Analiza przyczyn występowania uszkodzeń zmęczeniowych osi pojazdów szynowych. Praca badawczo-rozwojowa nr 5.5.130.916. AGH w Krakowie, czerwiec 2010.

[3] Zerbst U., Madler K., Hintze H.: Fracture mechanics in railway applications - an overview. Engineering Fracture Mechanics 2005, Vol. 72, s. 163-194.
[4] Szelążek J., Grzywna P., Gutkiewicz P., Mackiewicz S.: Zjawiska wpływające na wykrywalność pęknięć zmęczeniowych w eksploatacyjnych badaniach ultradźwiękowych osi kolejowych. Mat. XVIII Seminarium - Nieniszczące Badania Materiałów. Zakopane, marzec 2012, s. 37-49.

[5] Starzyński G., Szelążek J., Mackiewicz S.: Badania współczynnika odbicia i sztywności kontaktowej powierzchni chropowatych przy pomocy fal ultradźwiękowych. Mat. XVI Seminarium - Nieniszczące Badania Materiałów. Zakopane, marzec 2010, s. 53-66. 